\title{
Nested Buildings: An Innovative Strategy for the Integrated Seismic and Energy Retrofit of Existing Masonry Buildings with CLT Panels
}

\author{
Maria Rosa Valluzzi ${ }^{1}(0)$, Elisa Saler ${ }^{2, *}$, Alberto Vignato ${ }^{3}$, Matteo Salvalaggio ${ }^{1}\left({ }^{\circ}\right.$, Giorgio Croatto $^{3}$, \\ Giorgia Dorigatti ${ }^{3}(D)$ and Umberto Turrini ${ }^{3}(\mathbb{D}$ \\ 1 Department of Cultural Heritage, University of Padova, 35139 Padova, Italy; \\ mariarosa.valluzzi@unipd.it (M.R.V.); matteo.salvalaggio@unipd.it (M.S.) \\ 2 Department of Geosciences, University of Padova, 35131 Padova, Italy \\ 3 Department of Civil, Environmental, and Architectural Engineering, University of Padova, 35131 Padova, \\ Italy; alberto.vignato@unipd.it (A.V.); giorgio.croatto@unipd.it (G.C.); giorgia.dorigatti@unipd.it (G.D.); \\ umberto.turrini@unipd.it (U.T.) \\ * Correspondence: elisa.saler@unipd.it
}

Citation: Valluzzi, M.R.; Saler, E.; Vignato, A.; Salvalaggio, M.; Croatto, G.; Dorigatti, G.; Turrini, U. Nested Buildings: An Innovative Strategy for the Integrated Seismic and Energy Retrofit of Existing Masonry Buildings with CLT Panels. Sustainability 2021, 13, 1188. https:// doi.org/10.3390/su13031188

Academic Editor: Alberto Giretti Received: 30 December 2020

Accepted: 20 January 2021

Published: 23 January 2021

Publisher's Note: MDPI stays neutral with regard to jurisdictional claims in published maps and institutional affiliations.

Copyright: (c) 2021 by the authors. Licensee MDPI, Basel, Switzerland. This article is an open access article distributed under the terms and conditions of the Creative Commons Attribution (CC BY) license (https:/ / creativecommons.org/licenses/by/ $4.0 /)$.

\begin{abstract}
The Italian building heritage is aged and inadequate to the high-performance levels required nowadays in terms of energy efficiency and seismic response. Innovative techniques are generating a strong interest, especially in terms of multi-level approaches and solution optimizations. Among these, Nested Buildings, an integrated intervention approach which preserves the external existing structure and provides a new structural system inside, aim at improving both energy and structural performances. The research presented hereinafter focuses on the strengthening of unreinforced masonry (URM) buildings with cross-laminated timber (CLT) panels, thanks to their lightweight, high stiffness, and good hygrothermal characteristics. The improvement of the hygrothermal performance was investigated through a 2D-model analyzed in the dynamic regime, which showed a general decreasing in the overall thermal transmittance for the retrofitted configurations. Then, to evaluate the seismic behavior of the coupled system, a parametric linear static analysis was implemented for both in-plane and out-of-plane directions, considering various masonry types and connector spacings. Results showed the efficiency of the intervention to improve the in-plane response of walls, thus validating possible applications to existing URM buildings, where local overturning mechanisms are prevented by either sufficient construction details or specific solutions.
\end{abstract}

Keywords: nested buildings; seismic retrofit; energy efficiency; integrated intervention; built heritage; masonry buildings; CLT panels; timber

\section{Introduction}

Seismic and energetic retrofit interventions are one of the main challenges to ensure adequate building safety and comfort. Safety, in a more comprehensive sense, shall include sustainability, in the perspective of contrast to climate change and related risks. Most of existing buildings in the European Union were built without any energy performance requirement: $35 \%$ is over 50 years old, and almost $75 \%$ are inadequate to the current building standards in terms of energy efficiency, according to the Joint Research Centre report [1]. Improving energy efficiency of buildings is an essential component to fulfil the EU Commission's purpose to cut net greenhouse gas emissions by 55\% by 2030, respect to 1990, in the EU. With about 34 million Europeans who reported an inability to afford keeping their homes adequately heated in 2018 [2] renovation and retrofit interventions are also important to tackling energy poverty. In addition, the structural reliability of aged buildings is often inadequate, especially with regards to seismic actions, as observed after recent seismic events in EU seismic-prone countries (e.g., Athens, Greece 1999 [3,4]; L' Aquila, Italy 2009 [5-7]; Lorca, Spain 2011 [8-10]; Emilia, Italy 2012 [11,12]; and Central 
Italy $2016[13,14])$. The observed building collapses due to seismic events resulted in significant economic losses, severe injuries, and loss of human lives.

Both energetic and seismic retrofit present specific aspects that often lead to difficulties in defining intervention solutions that fulfil both targets. Thus, the development and optimization of integrated intervention technologies is a theme of growing importance and interest at international level. Recently, in Italy, a series of fiscal incentives in form of tax credit have been approved and financed in order to ease the implementation of both energetic, seismic and, above all, integrated interventions. It is the case of the so-called "Ecobonus" [15], for energetic retrofit, "Sismabonus" [16], for seismic improvements, and the more recent "Superbonus" [17], which increases the tax credit value up to $110 \%$ of the intervention costs.

In this framework, an innovative intervention strategy is proposed. It is defined by the Nested Building (NB) approach, which enables to retrofit and reuse existing buildings by (i) preserving the external envelope, (ii) removing the internal elements, and (iii) inserting a new inner coat layer with high structural and thermal performances. This intervention allows for the integrated design and optimization of both structural and energy retrofit maintaining the façade, so that it can be suitable in presence of historical constraints requiring external preservation [18].

The feasibility and the efficiency of NBs, in terms of both energy efficiency and seismic performance are here analyzed by taking into consideration the retrofit of unreinforced masonry (URM) existing buildings by means of cross-laminated timber (CLT) panels. CLT is a quasi-rigid composite, commonly formed by an uneven number of timber layers arranged orthogonally to each other; due to its capability to bear both in-plane and out-ofplane loads, CLT can be used for planar elements (floors and walls) [19-22]. The integrated intervention requires to couple the external existing walls with CLT panels, in order to improve the global seismic strength, with a new inner insulation system to achieve high thermal efficiency and comfort standard. In addition, the substitution of slabs with lighter CLT floors reduces seismic masses, thus providing an advantage in terms of mechanical behavior of the retrofitted structure. Figure 1 illustrates a scheme of the NB intervention phases.

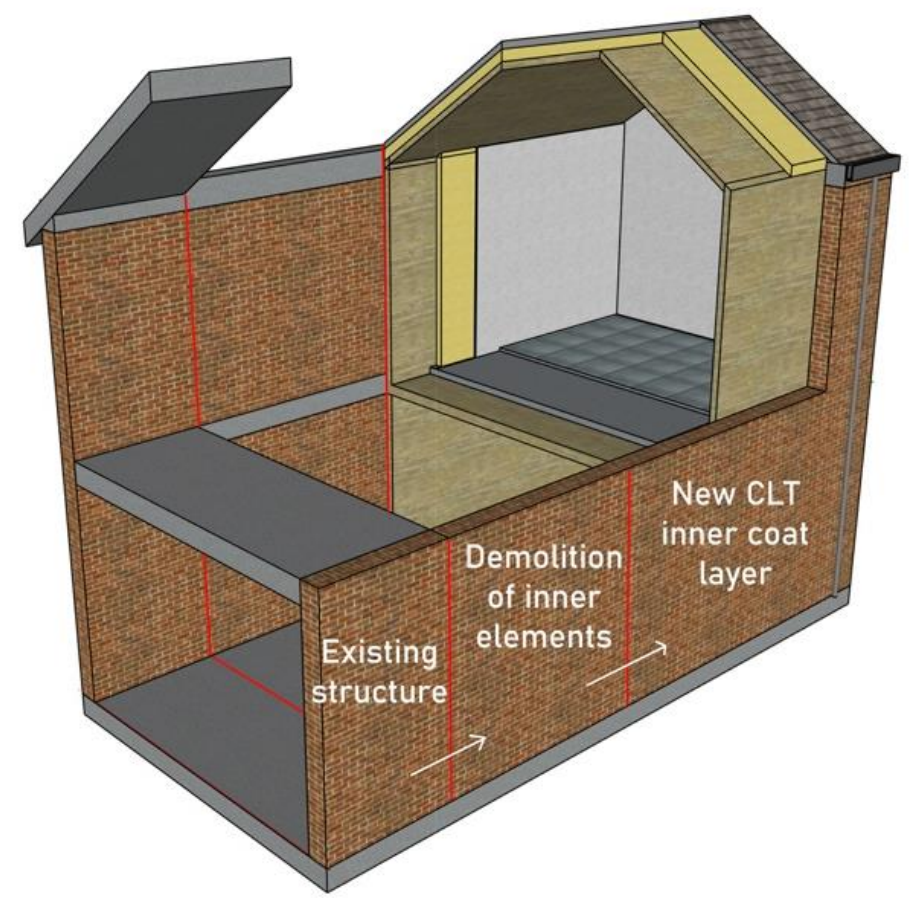

Figure 1. Schematization of Nested Building (NB) intervention phases. 
The usage of timber elements within masonry buildings dates back to the origin of ancient civilizations, due to the spread of wood sources, the high workability of timber, and the mechanical compatibility of wooden and masonry elements. Timber elements (such as beams, lintels, floors, and roofs) were widely used in the built heritage until the advent of steel and reinforced concrete (r.c.), that restricted them to traditional or handcrafted solutions. The use of r.c. slabs in unreinforced masonry buildings, in place of traditional timber diaphragms, had dire consequences in seismic prone areas, as shown after earthquakes occurred in Italy since 90s [23,24].

Then, research has moved towards the rehabilitation of traditional timber components and the improvement of their mechanical characteristics through compatible techniques, whose main lines regard (i) the stiffening of timber diaphragms and (ii) the strengthening of masonry walls through timber frames or panels $[25,26]$.

Traditional and innovative strengthening techniques of timber beams were assessed by Valluzzi et al. [27-29]: diaphragms strengthening and stiffening techniques above traditional floors (composed by support beams and one simple transverse boarding) were tested in laboratory and good performances were obtained with superimposition of $45^{\circ}$ double planking. Experimental and analytical studies on vintage timber floors performances were made by Giongo et al. [30]. The influence of strengthened timber floors on the dynamic behavior of URM structures were assessed, by means of numerical simulations, in Scotta et al. [31] and in Salvalaggio et al. [32]; results showed the importance of floors improvement in the seismic capacity of URM buildings. Nevertheless, the improvements of seismic response due to floors stiffening rely on proper quality of masonry walls and of wall-to-diaphragm connections, which are often a weakness of existing buildings [33]. Non-retrofitted vintage timber-steel connections and retrofitted ones with new nails were compared in Schiro et al. [34]. Furthermore, vintage wall-to-diaphragm plate anchors were tested in situ by Dizhur et al. [35] and Giaretton et al. [36]. All these last three studies showed that lower performances of vintage specimens can be related, case by case, to both steel connectors and timber status.

Strengthening techniques aimed ai increasing URM walls capacity by coupling with wooden elements rely on (i) the capacity of connectors to bear the loads and (ii) the embedment strength of masonry unit in preventing splitting phenomena. The efficiency of seismic retrofitting of URM walls by means of timber strong-backs were tested and described in [37,38], while CLT-URM coupling solutions are shown in [39], where connections between the two leaves were lumped at the floor levels of the building. An integrated seismic and energetic retrofit intervention with CLT panels was proposed for both URM and r.c. frames in Sustersic et al. $[40,41]$. The intervention consisted in the application of a novel outer shell made of aerogel insulation and CLT and was further investigated through shaking-table tests on two-stories r.c. frames, with, and without, masonry infills [42]. In Riccadonna et al. [43], the study of dry connections joining timber and URM suggested the use of mild steel fasteners for clay brick units, whereas hardened carbon steel elements were recommended to prevent brittle failure in stone elements. In this regard, stone masonry-timber elements connections strengthened with injection anchors were tested in Moreira et al. [44], while a study about tension and shear failure of anchorage systems in limestone, usually found in the heritage built, is described in Shedde et al. [45]. Very recently, Damiani et al. [46] proposed a new seismic retrofit technique to strengthen cavity walls by means of timber frames investigated through an extensive experimental campaign. A combined energetic and seismic retrofit intervention that applies CLT panels on existing r.c. frames was proposed by Margani et al. [47].

Focusing on energy-efficiency, retrofit interventions can be bound to operate only on the inner part of the building envelope, thus preserving the façade (e.g., for historical buildings) and providing an internal insulation system that changes the building hygrothermal conditions. Indeed, several studies focused on the effects and optimization of inner thermal insulation systems by means of experimental tests, monitoring, and simulations [48-51]. Moradias et al. [52] studied the hygrothermal behavior of retrofit solutions applied to the 
inner surface of old stone masonry rural buildings. The study highlighted the importance of repairing in order to minimize the risk of condensation. Abdul et al. [53] carried out a hygrothermal analysis on solid brick masonry panels of two case studies, with, and without, an inner thermal insulation system. The research pointed out the increasing risk of mold growth due to solar-driven vapor in case of biological materials on the exterior surface of the vapor barrier. Furthermore, the precipitation uptake was demonstrated to be the strongest factor to favor biological growth.

Focusing on CLT, in new building construction, the good thermal characteristics of timber, coupled with insulation materials, provide excellent energy performance rate, even though, as for most wood products, CLT is subjected to durability problems when exposed to prolonged moisture [54]. Thus, to guarantee an adequate service life to CLT buildings, hygrothermal performances shall be deeply investigated and fast drying shall be ensured $[55,56]$. Numerical simulations validated by means of small-scale experimental tests also showed that mineral wood insulation shall be avoided to reduce mold growth risk [57]. In addition, the lack of thermal mass together with the thermal transmittance of CLT increase the risk of overheating in hot season, which shall be taken into account in the design, especially in terms of expected increase in risk of overheating due to climate change [58,59].

Nevertheless, currently, the hygrothermal properties of the combined CLT-masonry system have not been fully investigated, due to the strong innovation of the solution.

In this paper, the integrated solution was studied by means of hygrothermal simulations, and of numerical finite element (FE) modelling through two validated software (Dartwin Mold Simulator [60] and Straus7 [61]) on an idealized wall panel representing a slender pier. The analyzed configuration allowed the evaluation of both the energetic performance of the section of the hybrid system and the seismic behavior of a single structural element, thus reducing parameters which affect the results. Both stone and clay block masonry were taken into consideration for the existing URM wall; steel bars were used to connect the CLT panel to the masonry wall to improve the seismic response avoiding, at the same time, the development of thermal bridges and the consequent drop in hygrothermal performance.

\section{Research Methods}

Nested buildings represent an innovative approach to the reuse of existing buildings that permit to reach technological, energy saving and indoor comfort levels comparable to new-built ones. The intervention strategy provides the preservation of the original façades while floor slabs and internal partitions are demolished, and a new inner structure is built up improving both seismic and energy-efficiency performances. Hence, NB intervention is compatible with buildings whose façades have high historical value while it is unsuitable for other heritage buildings subjected to specific limitations. It must be observed that construction phases and construction site planning are fundamental for this type of intervention.

Various solutions are available to create the new internal structure: reinforced concrete, steel, timber frames, and CLT panels. For each type, a brief description of the main features is presented in the following.

R.c. offers high stiffness and adaptability and permits effective structural connections between the new and the existing structure, due to reinforcing bars embedded in the existing wall. Nevertheless, concrete has high thermal transmittance, which causes significant thermal bridges if the structure is not adequately designed. Furthermore, construction site planning for installation and casting can become very complex in presence of the existing structure.

Steel frames also offer effective structural performances but, due to their high slenderness, they tend to develop greater displacements than masonry under seismic actions, especially in the case of historic buildings with very thick walls. To overcome the stiffness difference between the old structure and the new one, steel may need to be prestressed [62]. 
The strong precast level of steel structures permits easier installations, thus reducing both construction time and employed labor, even though the structural element dimension strongly affects handling and construction site. In this case, disadvantages refer to the high costs and hygrothermal properties of steel, which has a very high thermal conductivity and could create important variations in the thermal flow.

Timber solutions present the advantages of lightweight and good thermal properties. Timber frames present low stiffness, making them suitable to strengthen thin masonry panels [46], but it could be insufficient to strengthen thick masonry walls. Instead, CLT panels, thanks to their elevated stiffness, permit to combine the advantages of installation of prefabricated elements with both structural and energetic efficiency, making the intervention very competitive. Moreover, the CLT recyclability guarantees a good sustainability of the intervention lifecycle from both the environmental and economic points of view.

Table 1 summarizes the main features of the above-mentioned available solutions (i.e., reinforced concrete frame, steel frame, wooden frame, and cross-laminated panel).

Table 1. Comparison between different materials for new inner structure.

\begin{tabular}{|c|c|c|c|}
\hline & Structural Properties & Hygrothermal Properties & Construction Site \\
\hline R.c. frame & $\begin{array}{l}\text { - } \quad \text { High stiffness } \\
\text { - } \quad \text { Good connection to existing walls }\end{array}$ & $\begin{array}{l}\text { - } \quad \text { High thermal conductivity } \\
\text { - } \quad \text { Risk of thermal bridges }\end{array}$ & $\begin{array}{l}\text { Difficult casting stage due to } \\
\text { presence of existing structure } \\
\text { Irreversible }\end{array}$ \\
\hline Steel frame & $\begin{array}{l}\text { - } \quad \text { High strength and stiffness } \\
\text { Prestress required to ensure } \\
\text { structural collaboration with } \\
\text { existing portion }\end{array}$ & $\begin{array}{l}\text { - } \quad \text { High thermal conductivity } \\
\text { - } \quad \text { Risk of thermal bridges }\end{array}$ & $\begin{array}{l}\text { - } \\
\text { pot always simple handling of } \\
\text { - } \quad \text { Fast installation } \\
\text { - } \quad \text { Reversible due to dry connections }\end{array}$ \\
\hline Wooden frame & $\begin{array}{l}\text { - } \quad \text { Great lightweight } \\
\text { Low stiffness and great } \\
\text { deformability } \\
\text { - Suitable only for thin masonry } \\
\text { panels }\end{array}$ & $\begin{array}{l}\text { Good thermal properties but not } \\
\text { covering building envelope } \\
\text { Reduced durability when } \\
\text { exposed to prolonged moisture }\end{array}$ & $\begin{array}{ll}\text { - } & \text { Easy handling due to lightweight } \\
\text { - } & \text { Fast installation } \\
\text { - } & \text { Reversible and recyclable } \\
\text { (sustainable) }\end{array}$ \\
\hline CLT panel & $\begin{array}{l}\text { - } \quad \text { Significant lightweight } \\
\text { - } \quad \text { High stiffness }\end{array}$ & $\begin{array}{l}\text { - } \quad \text { Good thermal properties } \\
\text { Reduced durability when } \\
\text { exposed to prolonged moisture }\end{array}$ & $\begin{array}{l}\text { - Facilitate handling due to } \\
\text { lightweight, possible difficult } \\
\text { in-site assembly movements due } \\
\text { to presence of existing structure } \\
\text { - } \quad \text { Fast installation } \\
\text { - } \\
\text { Reversible and recyclable } \\
\text { (sustainable) }\end{array}$ \\
\hline
\end{tabular}

\subsection{Intervention Layout and Configurations}

The proposed intervention strategy may have a significant impact, but it guarantees a good degree of adaptability in the recovery and refurbishment phases. A series of intervention schemes were developed and shown in Table 2 with demolition phases (in yellow) and the assembly of novel structural elements (in red). The intervention can be applied to the entire building envelope or to only a portion of the floors. In the latter case, the portion excluded from the intervention shall be adequately verified to ensure the seismic improvement of the whole structural system. Indeed, the seismic performance improvement is favored by the reduction in seismic masses given by slab substitution with lighter CLT floors. In case of intervention at the ground floor, a foundation system shall be provided to the new inner structure; in other cases, an adequate load transfer system between the new and the existing structures shall be devised. Various retrofitted configurations are provided whether the roof and the internal walls are removed, or they are maintained. Each configuration requires a detailed evaluation of the construction site and installation phases, for instance, the evolution of the structural static scheme (e.g., thrusting roof no longer constrained by the upper floor) or the size of CLT panels that 
can be managed within the encumbrance of the standing structure. Possibly, provisional structures can be adopted.

Table 2. Example of intervention schemes based on demolition (yellow) and construction (red) phases.

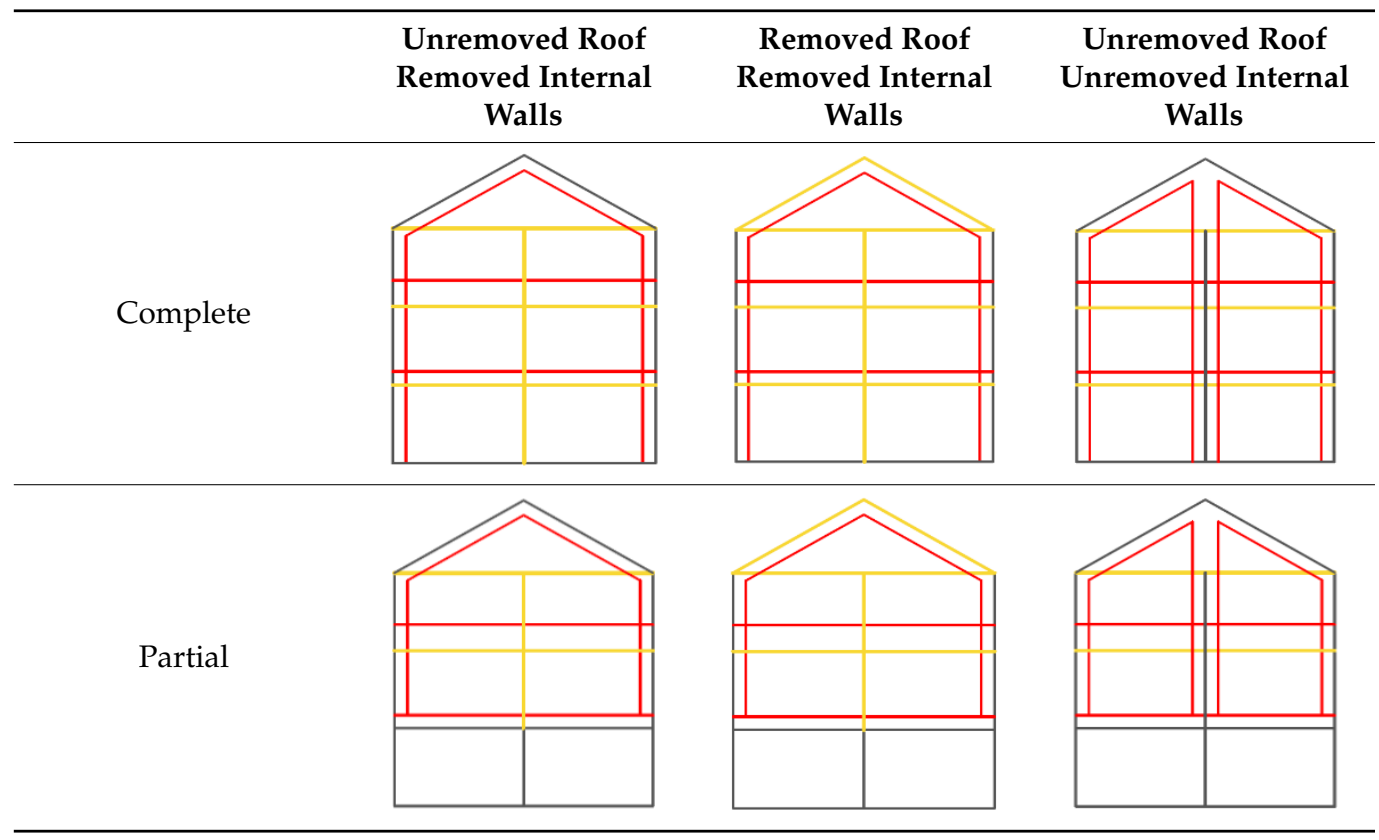

The analyzed configurations here presented concern both stone and clay masonry walls connected to a $100 \mathrm{~mm}$ thick CLT panel by means of stainless-steel bars grouted with epoxy resin and fastened to CLT by a bolted plate. The mechanical properties of CLT and of Glue Laminated Timber (i.e., the material of the laminate layers), refer to EN 14080:2013 [63], whereas its hygrothermal properties were in agreement with the Italian code UNI 10351:2015 [64].

Stainless steel EN 1.4016 (corresponding to AISI 430, according to the Italian code) was used for the connectors, whose mechanical properties refer to EN 10088-3:2014 [65].

As regards the stone masonry, both an "as-built" wall with weak mortar and a stone masonry consolidated by means of well executed grout injections were taken into consideration. The masonry mechanical characteristics were defined following the Italian seismic code [66,67]; according to it, effective grout injections in stonework increase both Young's modulus and compression strength up to $50 \%$. Wall thickness values were assigned according to the masonry types, as representative of common ranges of the Italian building heritage, resulting in a stone masonry wall $65 \mathrm{~cm}$ thick and a hollow clay block masonry wall $30 \mathrm{~cm}$ thick. Masonry hygrothermal properties referred to the above-mentioned UNI 10351:2015 [64].

Tables 3-5 show the geometric, hygrothermal and mechanical properties of timber elements, steel connectors, and masonry types, respectively. 
Table 3. Geometric, hygrothermal [64], and mechanical [63] parameters of CLT panels.

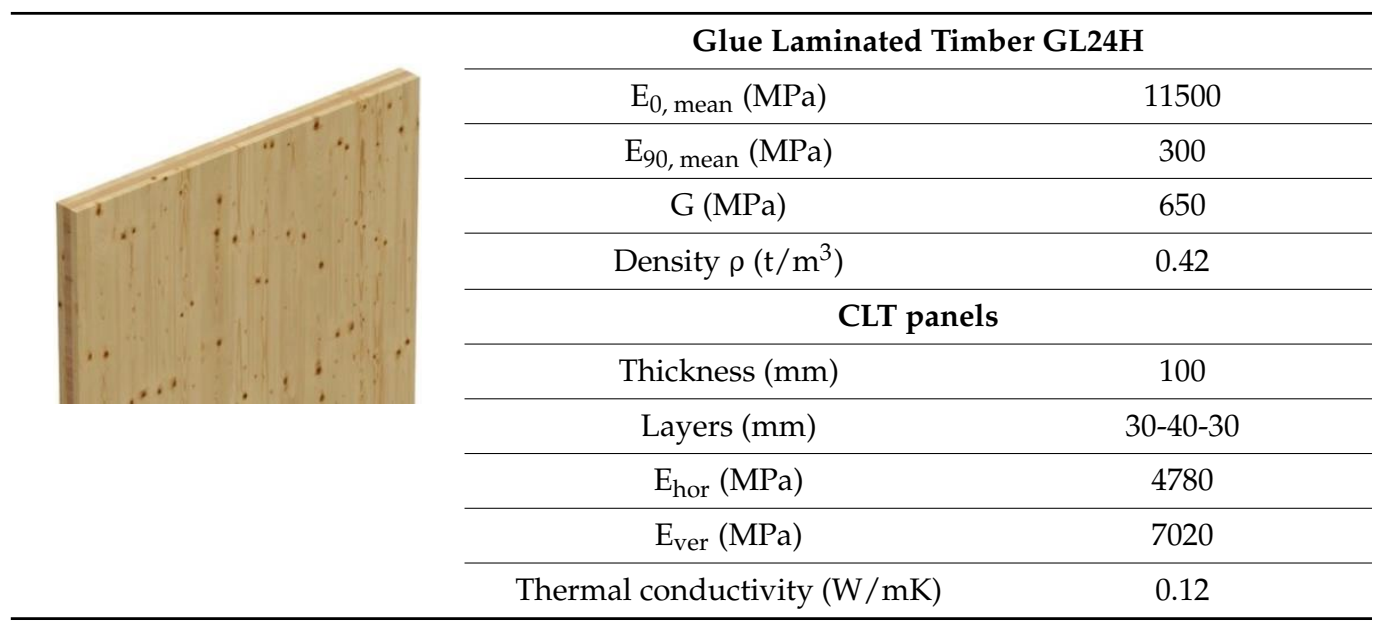

Table 4. Geometric, hygrothermal [64], and mechanical [65] parameters of steel connectors.

\begin{tabular}{|c|c|c|c|}
\hline \multirow{2}{*}{ 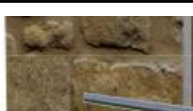 } & \multirow{4}{*}{ *. } & \multicolumn{2}{|c|}{ Stainless-Steel Connectors EN 1.4016/AISI 430} \\
\hline & & $\varnothing(\mathrm{mm})$ & 14 \\
\hline 4 & & $\mathrm{E}(\mathrm{MPa})$ & 220000 \\
\hline & & Yield strength $0.2 \%$ (MPa) & 240 \\
\hline . & & Thermal conductivity $(\mathrm{W} / \mathrm{mK})$ & 17 \\
\hline
\end{tabular}

Table 5. Geometric, hygrothermal [64], and mechanical [66,67] parameters of masonry walls.

\begin{tabular}{cccc}
\hline & \multicolumn{2}{c}{ Stone Masonry } & Hollow Clay \\
\cline { 2 - 3 } & Weak Mortar & Injections & Block Masonry \\
\hline Density $\rho\left(\mathrm{t} / \mathrm{m}^{3}\right)$ & 2.14 & 2.14 & 1.52 \\
\hline Wall thickness $(\mathrm{cm})$ & 65 & 65 & 30 \\
\hline Mean compression strength fc $(\mathrm{MPa})$ & 2.6 & 3.9 & 5.0 \\
\hline Elastic Modulus Em $(\mathrm{MPa})$ & 1740 & 2610 & 4550 \\
\hline Thermal conductivity $(\mathrm{W} / \mathrm{mK})$ & 3.5 & 3.5 & 0.36 \\
\hline
\end{tabular}

The energy-efficiency retrofit required the realization of an insulation system at the intrados of the CLT panel. The inner stratigraphy analyzed here consisted in a rock wool layer $80 \mathrm{~mm}$ thick, a vapor barrier and a double plasterboard sheet. To avoid moisture and mold growth, a vapor retarder was also inserted at the interface between the existing masonry and the wooden panel; Figure 2 represents, as an example, the intervention on a stone masonry wall. The properties of the inner insulation system components (Table 6) were assigned according to UNI 10351:2015 [64].

Table 6. Properties of inner insulation system components [64].

\begin{tabular}{ccc}
\hline & Rock Wool & Double Sheet Plasterboard \\
\hline Density $\rho\left(\mathrm{t} / \mathrm{m}^{3}\right)$ & 0.04 & 0.9 \\
\hline Thickness $(\mathrm{mm})$ & 80 & 25 \\
\hline Thermal conductivity $(\mathrm{W} / \mathrm{mK})$ & 0.035 & 0.21 \\
\hline
\end{tabular}




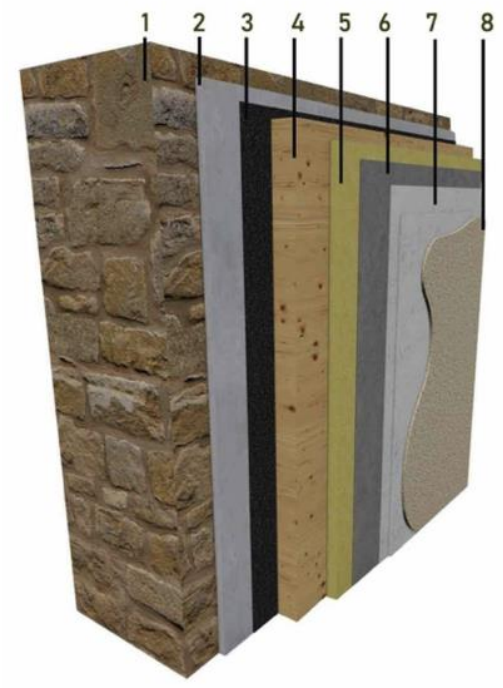

(a)

\author{
1- Stone masonry $(650 \mathrm{~mm})$ \\ 2- Plaster (15 mm) \\ 3- Vapor retarder \\ 4- CLT panel (100 mm) \\ 5- Rock wool $(80 \mathrm{~mm})$ \\ 6- Vapor barrier \\ 7- Double sheet plasteboard $(25 \mathrm{~mm})$ \\ 8- Internal finish (5 mm)
}

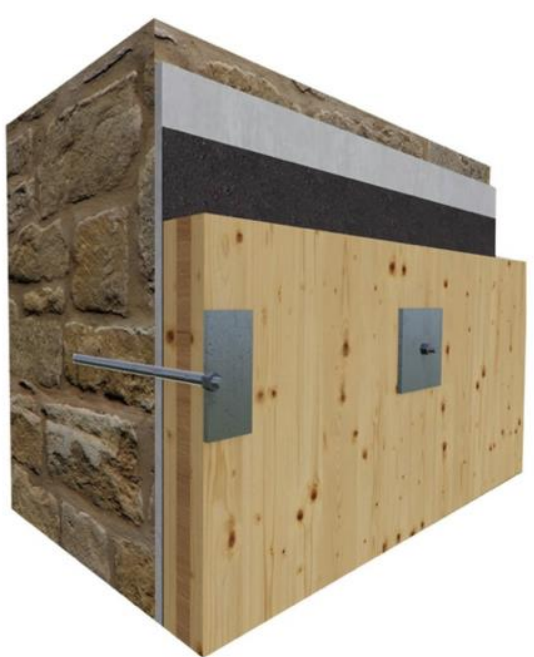

(b)

Figure 2. Example of stratigraphy of (a) post-intervention configuration and (b) focus on connectors.

\subsection{Hygrothermal Simulations}

Numerical simulations were carried out by means of Dartwin Mold Simulator 4 software [60], which provides analyses of both bidimensional and tridimensional models of stratigraphy and construction nodes, respectively. This software is based on the parameters and methodologies defined by EN ISO 6946:2017 [68] and by EN ISO 13786:2017 [69]. It subdivides the geometric model into a triangular mesh and then the energy conservation laws are applied to the model, resulting in a system of equations depending on the temperature at the mesh nodes. The iterative solution of the system provides the node temperatures. Then, the heat flow through the modelled surface is determined applying the Fourier's law to the temperature distribution.

For the model implemented in this study, both steady-state and dynamic analyses were carried out. A 2D-model with quadratic elements was developed of the external wall, which was $3 \mathrm{~m}$ high, representative of an average interstory height. As boundary conditions, the internal temperature, the minimum external temperature, and the relative humidity were set to $20{ }^{\circ} \mathrm{C}, 0{ }^{\circ} \mathrm{C}$, and $65 \%$, respectively, as required by current energy saving regulations $[70,71]$. Both the initial and the post-intervention configurations were analyzed. In the latter, four steel connectors $60 \mathrm{~cm}$ spaced were applied. The following parameters (with their unit of measurement according to IS) were calculated for each configuration, as defined by EN ISO codes [68,69], and used as comparators:

- Thermal transmittance under steady-state boundary conditions $U\left(W / m^{2} K\right)$

- Periodic thermal transmittance $Y_{m n}\left(W / m^{2} K\right)$

- Internal areal heat capacity $\mathrm{K}_{1}\left(\mathrm{~kJ} / \mathrm{m}^{2} \mathrm{~K}\right)$

- Decrement factor $\mathrm{f}(-)$

- Thermal time lag $\Delta \mathrm{t}(\mathrm{h})$

The steady-state thermal transmittance $U$ describes the heat flow through a unit area, in unit time for a unit difference in temperature, assuming steady-state boundary conditions. It is calculated as the reciprocal of the sum of the thermal resistance of each layer of the building partition $\left(R_{1}, R_{2}, \ldots R_{n}\right)$, including external and internal surfaces $\left(R_{\text {se }}\right.$, $\left.\mathrm{R}_{\mathrm{si}}\right)$, and air layers or cavities $\left(\mathrm{R}_{\mathrm{a}}\right)$.

The periodic thermal transmittance $Y_{m n}$ expresses the thermal transmittance recorded over a 24-h period. This parameter quantifies the ability of a building component to limit the heat flow rate $\left(\hat{\mathrm{q}}_{\mathrm{i}}\right)$ with dynamic-state boundary conditions, such as the variation of temperature during the day $\left(\hat{\mathrm{T}}_{\mathrm{e}}\right)$. 
The internal areal heat capacity $\mathrm{K}_{1}$ describes the capacity of a partition of absorbing heat flowing from its internal to its external side, assuming a unit area per unit difference in temperature in the span of $24 \mathrm{~h}$. This value takes into account the temperature swings on both sides of the surface. The detailed calculation of $\mathrm{K}_{1}$ was implemented according to Annex C of EN ISO 13786:2017 [69]. The formulation (Table 7) is based on the elements $\left(Z_{\mathrm{mn})}\right.$ of the heat transfer matrix $\mathrm{Z}$, which relates the complex amplitude of temperature and heat flow rate on one side of a component to that on the other side. Index 1 conventionally refers to the innermost layer, while index 2 indicates the external side. $T$ is the period of the variations.

Table 7. Equations of thermal parameters $[68,69]$.

\begin{tabular}{cc}
\hline $\mathrm{U}\left(\mathrm{W} / \mathrm{m}^{2} \mathrm{~K}\right)$ & $\frac{1}{\mathrm{R}_{\mathrm{se}}+\sum_{\mathrm{i}=1}^{\mathrm{n}} \mathrm{R}_{\mathrm{i}}+\mathrm{R}_{\mathrm{a}}+\mathrm{R}_{\mathrm{si}}}$ \\
\hline $\mathrm{Y}_{\mathrm{mn}}\left(\mathrm{W} / \mathrm{m}^{2} \mathrm{~K}\right)$ & $\frac{\hat{\mathrm{q}}_{\mathrm{i}}}{\hat{\mathrm{T}}_{\mathrm{e}}}$ \\
\hline $\mathrm{K}_{1}\left(\mathrm{~kJ} / \mathrm{m}^{2} \mathrm{~K}\right)$ & $\mathrm{K}_{1}=\frac{\mathrm{T}}{2 \pi} \times\left|\frac{\mathrm{Z}_{11}-1}{\mathrm{Z}_{12}}\right|$ \\
\hline $\mathrm{f}(-)$ & $\frac{\left|\mathrm{Y}_{\mathrm{m}, \mathrm{n}}\right|}{\mathrm{U}}$ \\
\hline
\end{tabular}

The decrement factor $\mathrm{f}$ is calculated as the ratio between the modulus $\mathrm{Y}_{\mathrm{mn}}$ and $\mathrm{U}$.

At last, the thermal time lag $\Delta t$ corresponds to the time delay between the peak of the heat flux and the maximum amplitude of its effects, i.e., the time it takes for the heat waves to pass through each layer of the building partition. This lag occurs because of the heat buffering effect of the wall surfaces and it is proportional to the heat capacity of the building partition.

Table 7 reports the equations of the above-described parameters.

The temperature of the inner surface was also computed for the analyzed configurations, in order to assess the chance of moisture and mold growth and the relative mitigation given by the intervention.

The phenomenon of mold growth and moisture mainly depends on three parameters: the inner temperature, the internal humidity, and the inner surface temperature [72,73]. The development of condensation and mold occurs when the surface temperature is lower than the related dew temperature, which represent the saturation point of air [74]. The dew temperature can be evaluated through the psychrometric chart [75], also known as Carrier's chart, which is a graphical representation of the main parameters of humid air at a constant pressure (i.e., dry-bulb temperature, humidity ratio, wet bulb, or saturation temperature). It is commonly used in the literature to evaluate the dew point temperature [76,77]. Assuming a relative humidity equal to $65 \%$ and an inner dry-bulb temperature $[78,79]$ of $20{ }^{\circ} \mathrm{C}$, the resulting dew temperature is $13.2^{\circ} \mathrm{C}$, which represent the minimum threshold value of the inner surface temperature to avoid condensation.

Molds tend to grow in environments with a greater relative humidity equal to $80 \%$ [72]. However, these conditions cannot be neglected, as they represent common humidity peaks linked to various human activities. According to the psychrometric chart, the dew point for the mold growth (with a relative humidity equal to $80 \%$ and an inner temperature of $20{ }^{\circ} \mathrm{C}$ ) corresponds to $16.5^{\circ} \mathrm{C}$.

Section 3.1 shows the results of the hygro-thermal analyses for the "as built" and the retrofitted configurations.

\subsection{FE Modeling for Parametric Seismic Analyses}

The seismic behavior of the innovative solution was analyzed both in-plane (IP) and out-of-plane (OOP) by a finite element (FE) model of a slender masonry wall, combined with a CLT panel. In addition, a parametric analysis was implemented to evaluate the effectiveness of various degrees of connection, taking into account both masonry types 
and spacing of the steel connectors. The masonry panel was $6 \mathrm{~m}$ high, corresponding to a two-story wall, and $1.2 \mathrm{~m}$ wide, to represent a slender pier. This can be traced back to a regular building with a large number of nearby openings.

The FE model was implemented in Straus7 2.4 software [61] by means of 2D plate elements for the walls, using 8-node quadrilateral elements (QUAD8), and beam elements for connectors; link elements were overlapped to connectors in order to concentrate the shear deformations at the interface between the masonry wall and the CLT panel. The CLT panel OOP displacements were constrained at the floor levels. To evaluate the possible degree of connection, the foundation was considered fixed and the connection to CLT were the only boundaries for the masonry walls. In this configuration, the seismic actions acted from floor masses to CLT panels, while masonry walls bore only self-weight and the consequent seismic inertial forces.

The parametric analysis also took into consideration various modeling schemes and boundary conditions between the CLT panel and the masonry pier (Figure 3). First, interface contact with no connector was modelled as base configuration, to be used as control model and evaluate the benefits of timber-masonry connections. Then, steel connectors were modelled considering two spacing values, i.e., $120 \mathrm{~cm}$ and $60 \mathrm{~cm}$.

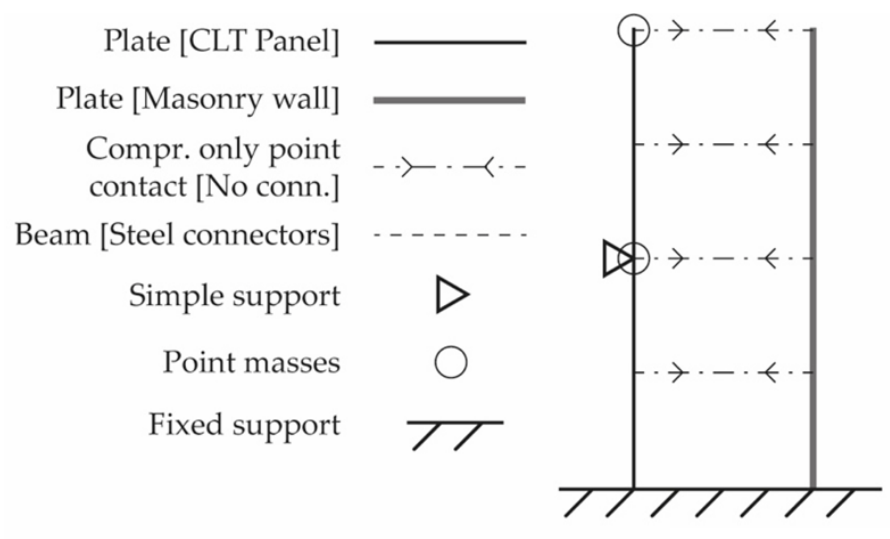

(a)

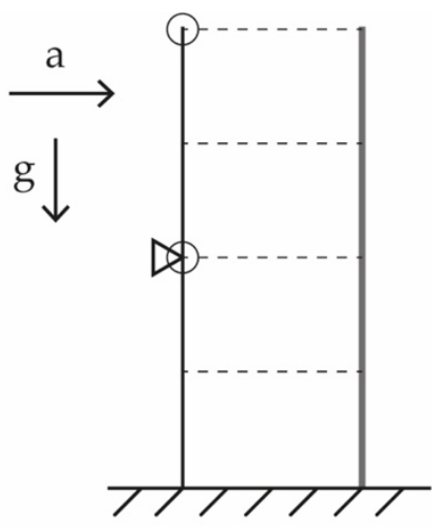

(b)

Figure 3. Modeling scheme with boundary conditions for (a) control model with no connector and (b) model with steel connectors.

An equivalent linear static analysis was implemented accounting for geometric nonlinearity, for both IP and OOP directions considering inertial forces compliant with a uniform acceleration of $0.2 \mathrm{~g}$, corresponding to a moderate seismic hazard [80], applied in 10 steps.

\section{Results}

\subsection{Improvement of Hygrothermal Performance}

The numerical simulations provided results to evaluate the thermal improvement given by the proposed intervention. Figures 4 and 5 show the isotherm distributions for the stone and the hollow clay block walls, respectively. The surface temperature is reported before and after the intervention for the minimum external temperature $\left(0^{\circ} \mathrm{C}\right)$ are reported, whereas Figure 6 shows its annual trend.

The increase in the internal surface temperature improved the thermal comfort in the heating seasons, and, as mentioned before, avoids moisture and mold growth, thus preserving the wooden structure. In both masonry types, the inner surface temperature increased to around $19^{\circ} \mathrm{C}$, greater than the dew temperatures related to the condensation and to the mold growth, as described in Section 2.1. In terms of surface temperature, the intervention appeared to be especially effective for the stone masonry wall, which in the "as 
built" configuration showed a value $\left(12.64^{\circ} \mathrm{C}\right)$ below the calculated minimum threshold $\left(13^{\circ} \mathrm{C}\right)$, with a significant risk in the formation of condensation and in the mold growth.

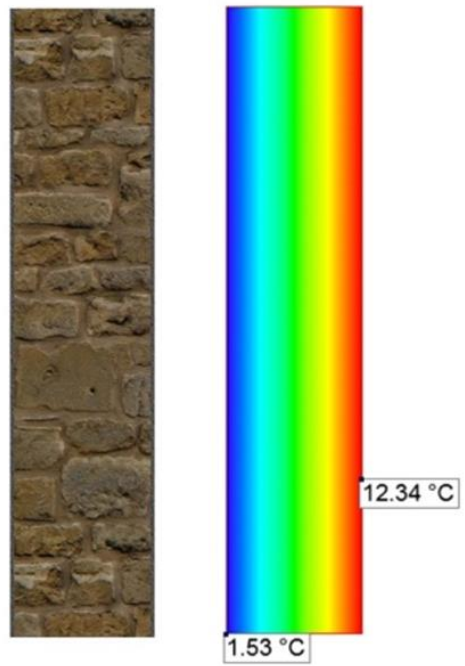

(a)
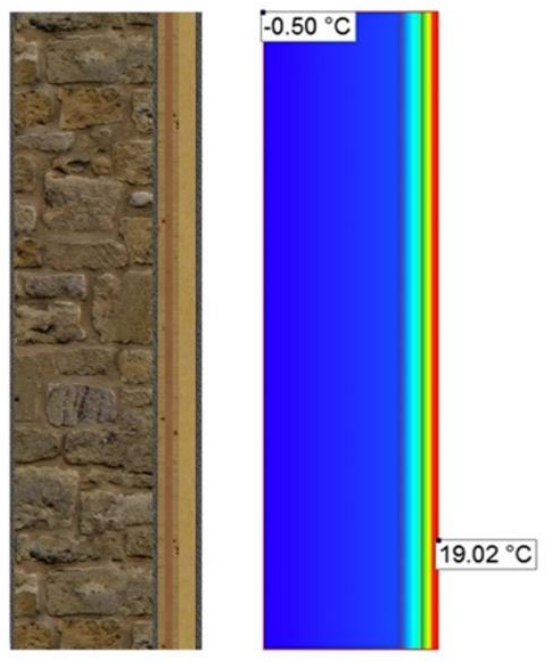

(b)
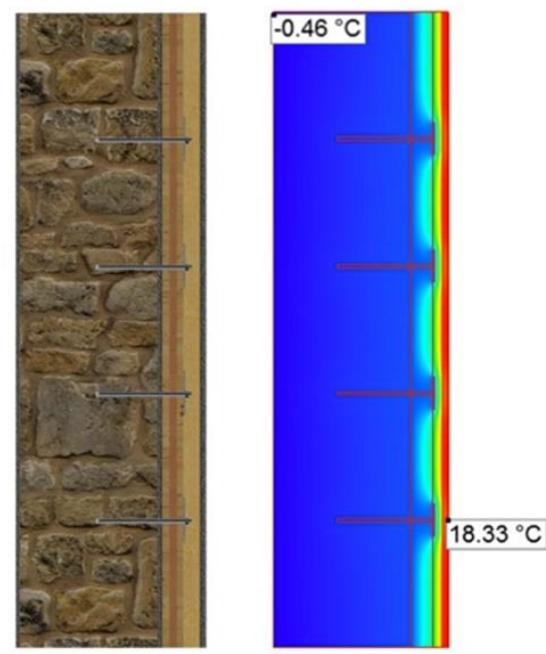

(c)

Figure 4. Isotherm distributions for sections of stone masonry wall: (a) pre-intervention (b) post-intervention, and (c) post-intervention in section corresponding to connectors.
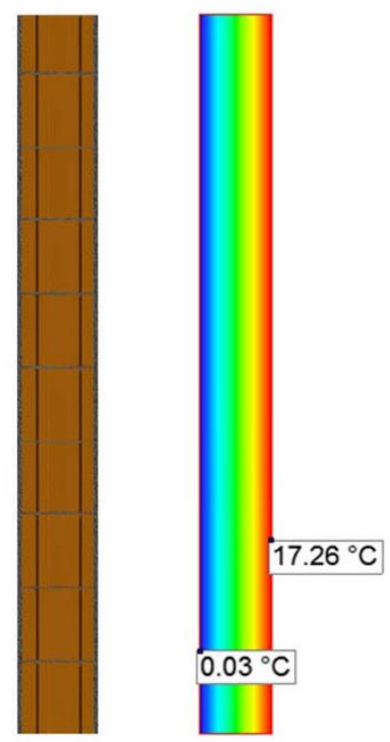

(a)
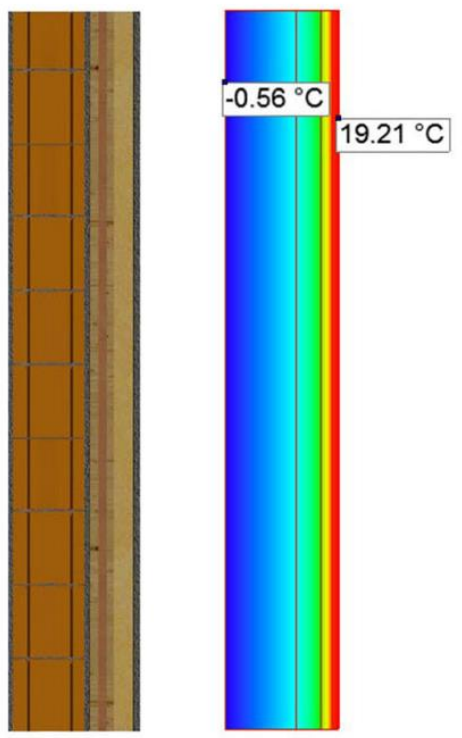

(b)
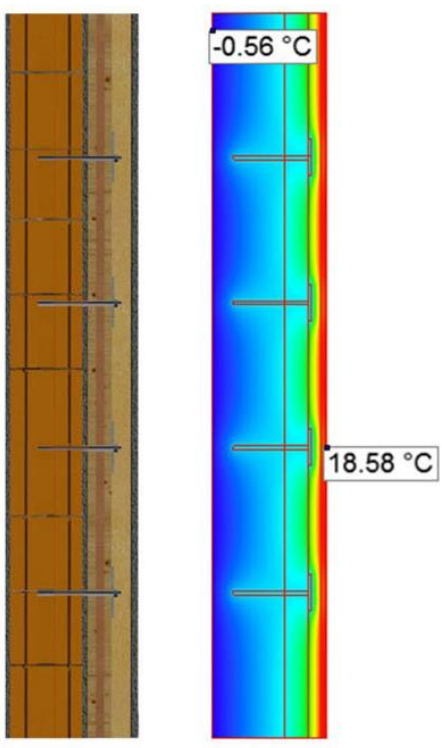

(c)

Figure 5. Isotherm distributions for sections of hollow clay block wall: (a) pre-intervention (b) post-intervention, and (c) post-intervention in section corresponding to connectors. 
Int temp $\left({ }^{\circ} \mathrm{C}\right)$

25

20

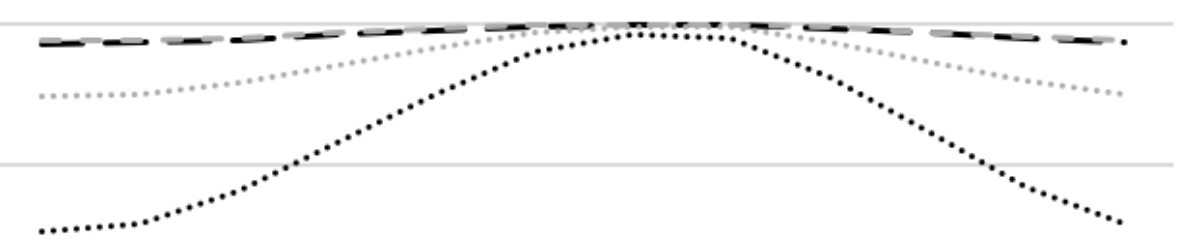

10

Stone pre-int

5

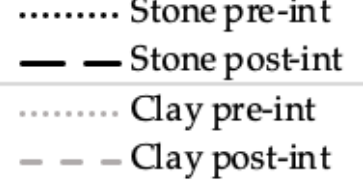

0

Jan Feb Mar Apr May Jun Jul Aug Sep Opt Nov Dec

Figure 6. Trends of internal surface temperature for one-year simulation.

In addition, in the post-intervention configurations, steel connectors did not affect the hygrothermal performance, with neither significant variation in the isotherm distribution nor presence of mold and interstitial condensation, due to their low thermal transmittance and not dense structural mesh.

The performance of the retrofitted building envelope was significantly improved compared to the initial configuration, as shown in Table 8.

Table 8. Results of hygrothermal simulations pre- and post-intervention.

\begin{tabular}{ccccc}
\hline & \multicolumn{2}{c}{ Stone Masonry } & \multicolumn{2}{c}{ Hollow Clay Block Masonry } \\
\cline { 2 - 5 } & Pre-Int & Post-Int & Pre-Int & Post-Int \\
\hline $\mathrm{U}\left(\mathrm{W} / \mathrm{m}^{2} \mathrm{~K}\right)$ & 2.798 & 0.278 & 0.997 & 0.235 \\
\hline $\mathrm{Y}_{\mathrm{mn}}\left(\mathrm{W} / \mathrm{m}^{2} \mathrm{~K}\right)$ & 0.270 & 0.007 & 0.282 & 0.006 \\
\hline $\mathrm{f}(-)$ & 0.096 & 0.024 & 0.283 & 0.026 \\
\hline $\mathrm{K}_{1}\left(\mathrm{~kJ} / \mathrm{m}^{2} \mathrm{~K}\right)$ & 85.96 & 14.79 & 59.42 & 15.66 \\
\hline$\Delta \mathrm{t}(\mathrm{h})$ & 2.84 & 12.43 & 3.00 & 13.90 \\
\hline
\end{tabular}

The steady thermal transmittance $U$ of the envelope significantly decreased, and, in both masonry configurations, the outcome values were smaller than $0.338 \mathrm{~W} / \mathrm{m}^{2} \mathrm{~K}$. This is the threshold provided by the Italian code DM 26/06/2015 [81], starting from 2021, for vertical opaque elements in existing buildings subjected to energy-efficiency retrofit by means of inner insulation system. Indeed, in case of internal intervention, the thresholds of thermal transmittance can be incremented by 30\%. This confirms that the proposed intervention meets the requirements given by the current codes [81].

Similarly, those codes limit the periodic thermal transmittance up to $0.10 \mathrm{~W} / \mathrm{m}^{2} \mathrm{~K}$ for the walls subjected to solar irradiation, with the aim of cutting energy need for the cooling conditioning. This also confirms that the proposed intervention fulfils this provision.

Due to the lightweight of the inner layers, the intervention led to a decrement in the internal areal heat capacity, which is strongly linked to the inner thermal mass. Indeed, the intervention aims at providing an integrated solution which improve both the energy efficiency and the seismic performance. Thus, for the latter, a decrease in the inertial 
masses is desirable, with the consequence decrease in the inner layer thermal masses. The performances of the retrofit solution in the heating season, compared to those in the cooling season, suggest the application of the intervention in climatic zones with mild summertime.

Nevertheless, the thermal time lag quadrupled, for both stone and clay masonry, approaching or overtaking the ideal value of $12 \mathrm{~h}$. A significant reduction in the decrement factor was observed; in case of stone masonry the retrofitted value was a quarter of the initial one, while the clay masonry showed a greater decrease in the decrement factor to less than a tenth of the "as built" value. The thermal time lag improvement and the reduction in the decrement factor, denoted the better comfort offered by the retrofitted solutions.

\subsection{Parametric Seismic Analysis on Numerical Model}

The seismic micro-model of the coupled wall was analyzed in term of system of deformations and maximum displacements both in the in-plane (IP) and in the out-ofplane (OOP) directions. Seismic action was represented in terms of acceleration; hence, results were affected not only by the stiffness of the system but also by the inertial masses, which are higher in case of thicker stone masonry.

Figure 7 shows the results in terms of IP maximum displacements for the control model (CM), so as to compare them with the outcomes of the other models and thereby to evaluate the IP displacement reduction given by the steel connectors. The stone masonry wall with weak mortar, which has large inertial mass and a low Young's modulus, reached the greatest IP maximum displacement, while the stone masonry wall with injections developed smaller displacements due to its higher stiffness. The hollow clay block masonry showed the lowest amplitude of deformations, mainly due to its small inertial mass, given its small thickness (and therefore stiffness). The CM cannot provide significant results in the OOP direction, for which the overturning mechanism of the masonry wall would be observed.

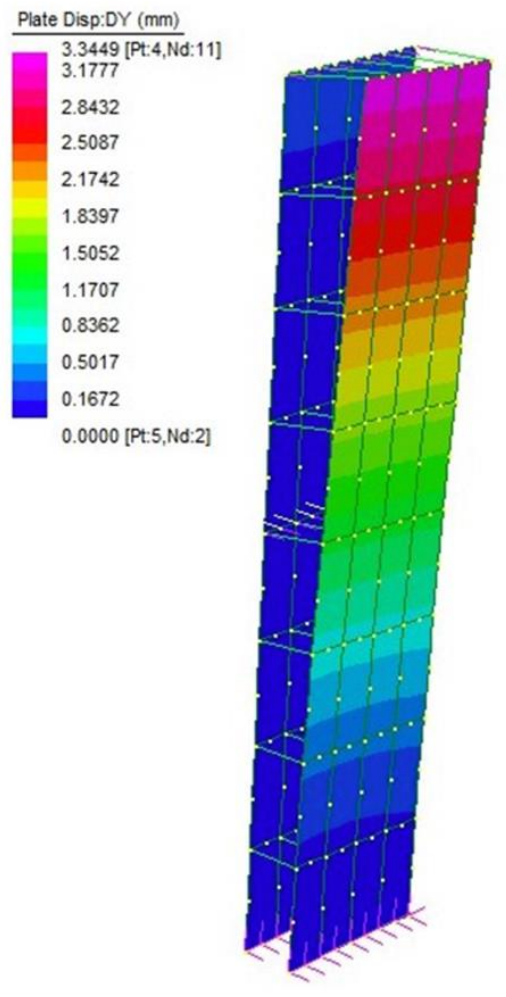

(a)
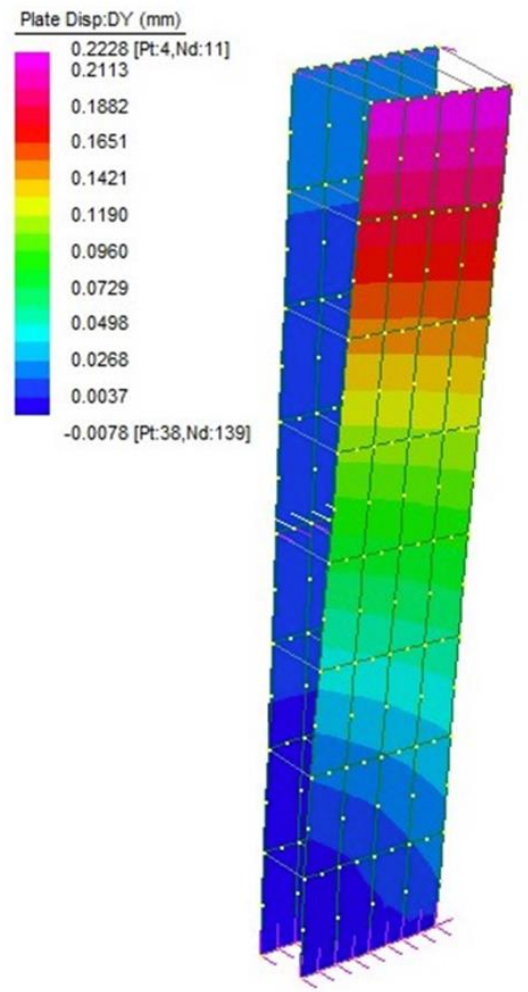

(b)
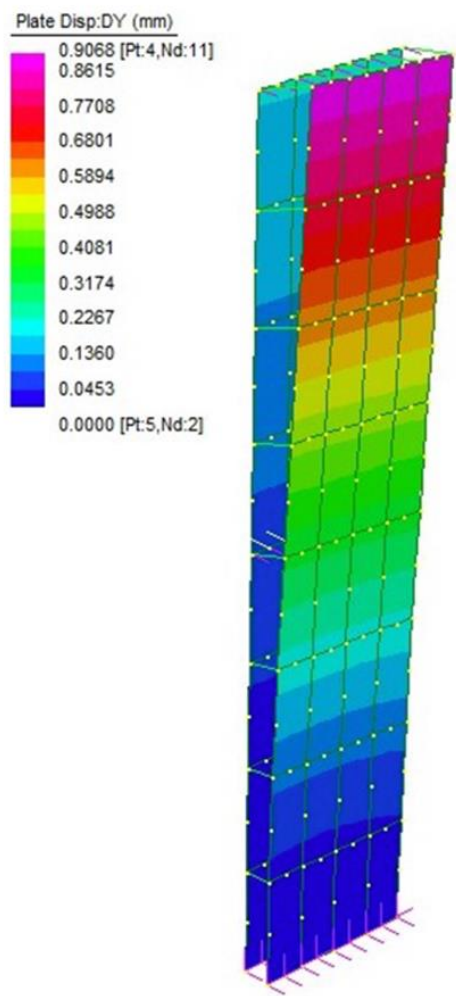

(c)

Figure 7. In-plane (IP) deformed shapes for control model (CM) with no connectors for (a) stone masonry w/weak mortar, (b) stone masonry w/injections, and (c) hollow clay block masonry. 
Tables 9 and 10 show results obtained for the models with steel connectors, in terms of deformed shapes and maximum displacements, respectively. Moreover, Table 10 reports the percentage reduction in IP displacement for the analyzed models compared to the CM.

Table 9. Results of IP and out-of-plane (OOP) deformed shapes for models with steel connectors.

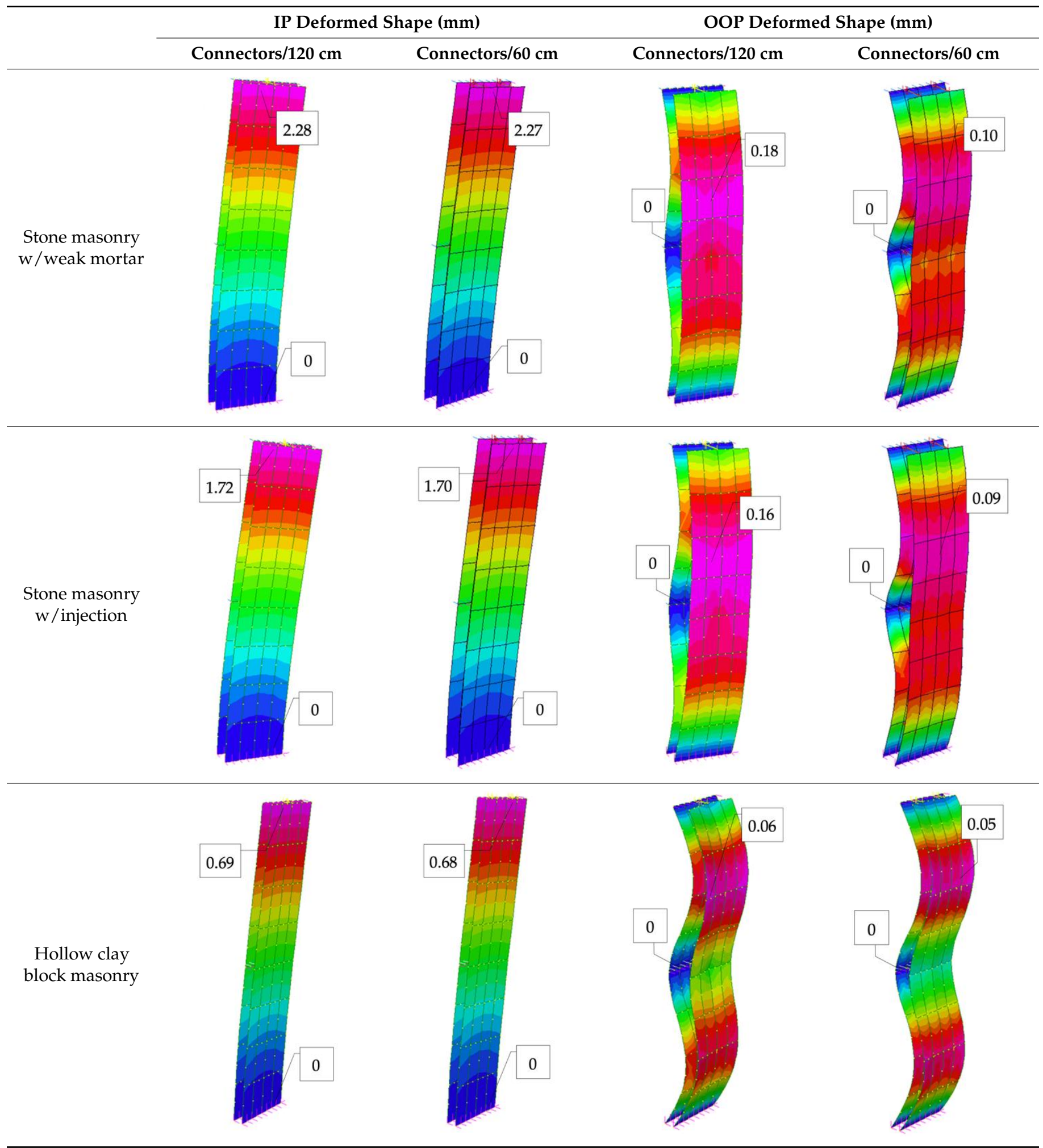


Table 10. Maximum in-plane and out-of-plane displacements of masonry wall in analyzed configurations.

\begin{tabular}{|c|c|c|c|c|c|}
\hline & \multicolumn{3}{|c|}{ IP Max Disp (mm) } & \multicolumn{2}{|c|}{ OOP Max Disp (mm) } \\
\hline & Control Model (CM) No Connector & $\mathrm{s} 120 \mathrm{~cm}$ & $\mathrm{~s} 60 \mathrm{~cm}$ & $\mathrm{~s} 120 \mathrm{~cm}$ & $\mathrm{~s} 60 \mathrm{~cm}$ \\
\hline \multirow{2}{*}{ Stone masonry w/weak mortar } & \multirow{2}{*}{3.34} & 2.28 & 2.27 & \multirow{2}{*}{0.18} & \multirow{2}{*}{0.10} \\
\hline & & $31.7 \%{ }^{1}$ & $32.0 \% 1$ & & \\
\hline \multirow{2}{*}{ Stone masonry w/injections } & \multirow{2}{*}{2.23} & 1.72 & 1.70 & \multirow{2}{*}{0.16} & \multirow{2}{*}{0.09} \\
\hline & & $22.8 \%{ }^{1}$ & $23.7 \%{ }^{1}$ & & \\
\hline \multirow{2}{*}{ Hollow clay block masonry } & \multirow{2}{*}{0.91} & 0.69 & 0.68 & \multirow{2}{*}{0.06} & \multirow{2}{*}{0.05} \\
\hline & & $24.2 \%{ }^{1}$ & $25.3 \% 1$ & & \\
\hline
\end{tabular}

${ }^{1}$ Reduction compared to the IP maximum displacement of the CM.

Results showed that the degree of coupling ensured by connectors reduced the IP displacements. Connectors in the sparse configuration $(120 \mathrm{~cm}$ spacing) significantly reduced the IP displacements with respect to the CM; no significant benefit was detected by increasing the number of connectors, halving spacing. The intervention increased the global stiffness of the system with a reduction in the IP displacements ranging from $20 \%$ to $30 \%$ (Table 10). The IP maximum displacement of the post-intervention configuration with sparse connectors applied to a stone masonry wall with injections was also compared to the one obtained from the control model of the stone masonry wall with weak mortar. The former developed an IP displacement of $1.72 \mathrm{~mm}$, while the latter reached $3.34 \mathrm{~mm}$. Thus, a combined intervention on a stone masonry wall, which comprised a preliminary grout injection and then the connection of the CLT panel to the masonry wall by means of sparse connectors, may decrease the IP maximum displacement of almost $50 \%$.

Results in terms of OOP maximum displacements showed the benefit of decreasing the connector spacing even though (see Table 9 for the developed deformed configurations), for the stone wall-CLT system, a satisfactory degree of coupling was yet to be reached, even in the denser configuration of steel connectors.

For the thinner clay block panel, good coupling was already reached with the largest connector spacing $(120 \mathrm{~cm})$. In this case, the thickening of connectors improved the effectiveness of the intervention in terms of deformed shape.

The OOP deformed configurations also pointed out the importance to provide a good connection of the masonry wall to the floors, which cannot be always ensured by the connectors to CLT walls. Thus, to avoid masonry OOP overturning mechanisms, it is fundamental to pay attention to all construction details to be designed case by case.

\section{Conclusions}

An innovative intervention on URM buildings by means of CLT panels has been proposed among Nested Building strategies. This intervention permits the integration and optimization of both energetic and seismic improvements by coupling the external existing masonry walls with inner CLT panels, which are able to enhance the global mechanical behavior and, by adding a new insulation system, to increase the energy efficiency. The coupled system was investigated by means of hygrothermal simulation and structural micro-modeling, with respect to two types of URM walls, i.e., stone masonry and hollow clay block masonry.

In case of a stone masonry wall $(65 \mathrm{~cm}$ thick), the integrated retrofit intervention showed, in terms of hygrothermal performance, a significant reduction in both the steady and the periodic thermal transmittance, reaching values of $0.278 \mathrm{~W} / \mathrm{m}^{2} \mathrm{~K}$ and $0.007 \mathrm{~W} / \mathrm{m}^{2} \mathrm{~K}$, respectively, both smaller than the reference values given by the Italian code [81]. The thermal time lag quadrupled reaching a value of $12.43 \mathrm{~h}$, while the retrofitted decrement factor was a quarter of the initial one, both indices of a better comfort offered by the retrofitted solution. In terms of seismic response, the simulation of the NB intervention showed an increment in the structural stiffness demonstrated by the significant reduction 
of the $30 \%$ in the IP maximum displacements. The results in terms of IP maximum displacements suggest that a combined intervention on a stone masonry wall, which comprised a preliminary grout injection and then the connection of the CLT panel to the masonry wall by means of sparse connectors, may decrease the IP maximum displacement of almost $50 \%$. However, the coupling in the OOP direction was not fully reached even with the minimum spacing of the connectors. Thus, the CLT-stone masonry connection may not be sufficient to exclude OOP mechanisms and a careful evaluation of construction details able to ensure the connection of masonry walls at floor levels is needed.

In case of application of the intervention to a hollow clay block masonry wall ( 30 $\mathrm{cm}$ thick), the improvement in the hygrothermal performance was demonstrated by a significant reduction in both the steady and the periodic thermal transmittance, reaching values of $0.235 \mathrm{~W} / \mathrm{m}^{2} \mathrm{~K}$ and $0.006 \mathrm{~W} / \mathrm{m}^{2} \mathrm{~K}$, respectively, both smaller than the reference values given by the Italian code [81]. The thermal time lag increased up to $13.90 \mathrm{~h}$ and the decrement factor was less than a tenth of its "as built" estimation, which both indicate a significant improvement in the comfort of the retrofitted configuration. In terms of seismic response, the hollow clay block masonry showed a reduction of the $25 \%$ in the IP maximum displacements. The clay wall, which is characterized by smaller thickness, and thus OOP stiffness, besides a smaller inertial mass, seemed to be satisfactorily coupled with the CLT panel in the OOP direction.

Regardless of the type of masonry, in the post-intervention configurations, the internal areal heat capacity decreased due to the lower inner thermal mass, which was strongly related to the system inertial mass. In general, reducing inertial masses is desirable in terms of seismic behavior. Considering that the intervention aims to fulfil both the energetic and the seismic retrofit targets, it resulted in being optimized for the application in climatic zones with mild summertime.

This research presented a methodological approach to determine the feasibility and the potential improvement given by a new integrated intervention. The results of this parametric study can be used to design and assess optimized solutions in case studies.

Author Contributions: Conceptualization, M.R.V., G.C., and U.T.; methodology and formal analysis, E.S., A.V., M.S., and G.D.; writing-original draft preparation, A.V. and E.S.; writing-review and editing, E.S., M.S., M.R.V., and U.T.; visualization, A.V., E.S., and M.S.; supervision, project administration and funding acquisition, M.R.V. and U.T. All authors have read and agreed to the published version of the manuscript.

Funding: This work was supported by the CORE-WOOD (COmpetitive REpositioning of WOOD sector) Italian project, in the framework of POR-FESR 2014-2020 Line 1 Action 1.1.4 of the Veneto Region.

Institutional Review Board Statement: Not applicable.

Informed Consent Statement: Not applicable.

Data Availability Statement: All the resulting data are contained in this article.

Conflicts of Interest: The authors declare no conflict of interest. The funders had no role in the design of the study; in the collection, analyses, or interpretation of data; in the writing of the manuscript, or in the decision to publish the results.

\section{References}

1. Filippidou, F.; Jimenez Navarro, J. Achieving the Cost-Effective Energy Transformation of Europe's Buildings; EUR 29906 EN; Publications Office of the European Union: Luxembourg, 2019. [CrossRef]

2. European Commission. EU Commission Recommendation of 14/10/2020 on Energy Poverty; 14.10 .2020 C(2020) 9600 Final; European Commission: Brussels, Belgium, 2020; Volume 7.

3. Eleftheriadou, A.K.; Karabinis, A.I. Development of damage probability matrices based on Greek earthquake damage data. Earthq. Eng. Eng. Vib. 2011, 10, 129-141. [CrossRef]

4. Lekkas, E. The Athens earthquake (7 september 1999): Intensity distribution and controlling factors. Eng. Geol. $2001,59,297-311$. [CrossRef] 
5. Modena, C.; Valluzzi, M.R.; Da Porto, F.; Casarin, F. Structural aspects of the conservation of historic masonry constructions in seismic areas: Remedial measures and emergency actions. Int. J. Archit. Herit. 2011, 5, 539-558. [CrossRef]

6. Da Porto, F.; Munari, M.; Prota, A.; Modena, C. Analysis and repair of clustered buildings: Case study of a block in the historic city centre of L'Aquila (Central Italy). Constr. Build. Mater. 2013, 38, 1221-1237. [CrossRef]

7. D'Ayala, D.F.; Paganoni, S. Assessment and analysis of damage in L'Aquila historic city centre after 6th April 2009. Bull. Earthq. Eng. 2011, 9, 81-104. [CrossRef]

8. Hermanns, L.; Fraile, A.; Alarcón, E.; Álvarez, R. Performance of buildings with masonry infill walls during the 2011 Lorca earthquake. Bull. Earthq. Eng. 2014, 12, 1977-1997. [CrossRef]

9. Martínez-Cuevas, S.; Gaspar-Escribano, J.M. Reassessment of intensity estimates from vulnerability and damage distributions: The 2011 Lorca earthquake. Bull. Earthq. Eng. 2016, 14, 2679-2703. [CrossRef]

10. Romão, X.; Costa, A.A.; Paupério, E.; Rodrigues, H.; Vicente, R.; Varum, H.; Costa, A. Field observations and interpretation of the structural performance of constructions after the 11 May 2011 Lorca earthquake. Eng. Fail. Anal. 2013, 34, 670-692. [CrossRef]

11. Cattari, S.; Abbati, S.; Ferretti, D.; Lagomarsino, S.; Ottonelli, D.; Tralli, A. The seismic behaviour of ancient masonry buildings after the earthquake in Emilia (Italy) on May 20th and 29th, 2012 I La risposta delle costruzioni in muratura a seguito delle scosse del 20 e 29 Maggio 2012 in Emilia. Ing. Sism. 2012, 29, 87-119.

12. Penna, A.; Morandi, P.; Rota, M.; Manzini, C.F.; da Porto, F.; Magenes, G. Performance of masonry buildings during the Emilia 2012 earthquake. Bull. Earthq. Eng. 2014, 12, 2255-2273. [CrossRef]

13. Sorrentino, L.; Cattari, S.; da Porto, F.; Magenes, G.; Penna, A. Seismic behaviour of ordinary masonry buildings during the 2016 central Italy earthquakes. Bull. Earthq. Eng. 2019, 17, 5583-5607. [CrossRef]

14. Vettore, M.; Saretta, Y.; Sbrogiò, L.; Valluzzi, M.R. A New Methodology for the Survey and Evaluation of Seismic Damage and Vulnerability Entailed by Structural Interventions on Masonry Buildings: Validation on the Town of Castelsantangelo sul Nera (MC), Italy. Int. J. Archit. Herit. 2020, 1-26. [CrossRef]

15. D.R.L. 205/2017 Budget Low for the Year 2018; Official Gazette of the Italian Republic: Rome, Italy, 2017; pp. 1-198. (In Italian)

16. DM 58 28/02/2017 Guidelines for the Classification of the Seismic Risk of Buildings; Official Gazette of the Italian Republic: Rome, Italy, 2017; pp. 1-11. (In Italian)

17. DL n. 34 19/05/2020 Decreto-Legge Recante "Urgent Measures in the Field of Health, Support for Work and Economy, as well as Social Policies, Related to the Epidemiological Emergency"; Official Gazette of the Italian Republic: Rome, Italy, 2020.

18. Lucchini, A.; Mazzucchelli, E.S.; Mangialardo, S.; Persello, M. Façadism and CLT technology: An innovative system for masonry construction refurbishment. In Proceedings of the 4th IAHS World Congress on Housing-Sustainable Housing Construction, Funchal, Portugal, 16-19 December 2014.

19. Brandner, R. Production and Technology of Cross Laminated Timber (CLT): A state-of-the-art Report. Focus Solid Timber Solut. Eur. Conf. Cross Laminated Timber 2014, 3-36.

20. Flatscher, G.; Schickhofer, G. Shaking-table test of a cross-laminated timber structure. Proc. Inst. Civ. Eng. Struct. Build. 2015, 168, 878-888. [CrossRef]

21. Brandner, R.; Flatscher, G.; Ringhofer, A.; Schickhofer, G.; Thiel, A. Cross laminated timber (CLT): Overview and development. Eur. J. Wood Wood Prod. 2016, 74, 331-351. [CrossRef]

22. Izzi, M.; Casagrande, D.; Bezzi, S.; Pasca, D.; Follesa, M.; Tomasi, R. Seismic behaviour of Cross-Laminated Timber structures: A state-of-the-art review. Eng. Struct. 2018, 170, 42-52. [CrossRef]

23. Binda, L.; Gambarotta, L.; Lagomarsino, S.; Modena, C. A multilevel approach to the damage assessment and the seismic improvement of masonry buildings in Italy. Seism. Damage Mason. Build. 2019, 179-194. [CrossRef]

24. Giuffré, A. A Mechanical Model for Statics and Dynamics of Historical Masonry Buildings. In Protection of the Architectural Heritage Against Earthquakes; International Centre for Mechanical Sciences (Courses and Lectures); Petrini, V., Save, M., Eds.; Springer: Berlin, Germany, 1996.

25. da Porto, F.; Valluzzi, M.R.; Munari, M.; Modena, C.; Arêde, A.; Costa, A.A. Strengthening of Stone and Brick Masonry Buildings. In Strengthening and Retrofitting of Existing Structures. Building Pathology and Rehabilitation; Costa, A., Arêde, A., Varum, H., Eds.; Springer: Berlin, Germany, 2018; Volume 9. [CrossRef]

26. Valluzzi, M.R.; Sbrogiò, L. Vulnerability of Architectural Heritage in Seismic Areas: Constructive Aspects and Effect of Interventions. In Cultural Landscape in Practice; Lecture Notes in Civil Engineering; Amoruso, G., Salerno, R., Eds.; Springer: Berlin, Germany, 2019.

27. Valluzzi, M.R.; Garbin, E.; Dalla Benetta, M.; Modena, C. In-plane strengthening of timber floors for the seismic improvement of masonry buildings. In Proceedings of the 11th World Conference on Timber Engineering, Trento, Italy, 20-24 June 2010; Volume 2, pp. $1752-1757$.

28. Valluzzi, M.R.; Garbin, E.; Modena, C. Flexural strengthening of timber beams by traditional and innovative techniques. J. Build. Apprais. 2007, 3, 125-143. [CrossRef]

29. Valluzzi, M.R.; Garbin, E.; dalla Benetta, M.; Modena, C. Experimental characterization of timber floors strengthened by in-plane improvement techniques. Proc. Adv. Mater. Res. 2013, 778, 682-689. [CrossRef]

30. Giongo, I.; Dizhur, D.; Tomasi, R.; Ingham, J.M. Field testing of flexible timber diaphragms in an existing vintage URM building. J. Struct. Eng. 2015, 141, 1-11. [CrossRef] 
31. Scotta, R.; Trutalli, D.; Marchi, L.; Pozza, L. Seismic performance of URM buildings with in-plane non-stiffened and stiffened timber floors. Eng. Struct. 2018. [CrossRef]

32. Salvalaggio, M.; Sbrogiò, L.; Pavanetto, M.; Valluzzi, M.R. Evaluation of the effect of compatible interventions applied to horizontal components of URM buildings with EFM and FEM models. The case of palazzo carraro in Noale (Italy). Compdyn. Proc. 2019, 1, 1472-1481. [CrossRef]

33. Lin, T.J.; LaFave, J.M. Experimental structural behavior of wall-diaphragm connections for older masonry buildings. Constr. Build. Mater. 2012, 26, 180-189. [CrossRef]

34. Schiro, G.; Giongo, I.; Ingham, J.M.; Dizhur, D. Lateral performance of as-built and retrofitted timber diaphragm fastener connections. J. Mater. Civ. Eng. 2018, 30, 1-8. [CrossRef]

35. Dizhur, D.; Giaretton, M.; Ingham, J. URM wall-to-diaphragm and timber joist connection testing. Proc. Int. Mason. Soc. Conf. 2018, 1991-2005.

36. Giaretton, M.; Giongo, I.; Dizhur, D. Field testing of unreinforced masonry wall-to-diaphragm connection via through-bolt plate anchors and timber blocking. Mason. Int. 2019, 32, 63-71.

37. Dizhur, D.; Giaretton, M.; Giongo, I.; Ingham, J. Seismic retrofit of masonry walls using timber strong-backs. Struct. Eng. Soc. J. SESOC 2017, 30, 30-44.

38. Cassol, D.; Giongo, I.; Ingham, J.; Dizhur, D. Seismic out-of-plane retrofit of URM walls using timber strong-backs. Constr. Build. Mater. 2020, 121237. [CrossRef]

39. Pozza, L.; Evangelista, F.; Scotta, R. CLT used as seismic strengthener for existing masonry walls. In Proceedings of the Atti del XVII convegno ANIDIS “L'Ingegneria sismica in Italia”, Pistoia, Italy, 17-21 September 2017; pp. 210-220.

40. Sustersic, I.; Dujic, B. Seismic strengthening of existing buildings with cross laminated timber panels. World. 2012, 15, 19.

41. Sustersic, I.; Dujic, B. Seismic Strengthening of Existing Concrete and Masonry Buildings with Crosslam Timber Panels. Mater. Joints Timber Struct. Recent Dev. Technol. RILEM Bookser. 2014, 9, 713-723. [CrossRef]

42. Sustersic, I.; Dujic, B. Seismic Shaking Table Testing of a Reinforced Concrete Frame with Masonry Infill Strengthened with Cross Laminated Timber Panels. In Proceedings of the World Conference on Timber Engineering, WCTE 2014, Quebec, QC, Canada, 10-14 August 2014.

43. Riccadonna, D.; Giongo, I.; Schiro, G.; Rizzi, E.; Parisi, M.A. Experimental shear testing of timber-masonry dry connections for the seismic retrofit of unreinforced masonry shear walls. Constr. Build. Mater. 2019, 211, 52-72. [CrossRef]

44. Moreira, S.; Ramos, L.F.; Oliveira, D.V.; Lourenço, P.B. Experimental behavior of masonry wall-to-timber elements connections strengthened with injection anchors. Eng. Struct. 2014, 81, 98-109. [CrossRef]

45. Shedde, D.; Wang, Z.; Ingham, J.; Dizhur, D.; Porcarelli, S. Tension and shear behaviour of anchorage systems in limestone structures. In Proceedings of the NZSEE 2020 Annual Conference, Wellington, New Zealand, 22-24 April 2020.

46. Damiani, N.; Miglietta, M.; Guerrini, G.; Graziotti, F. An innovative timber system for the seismic retrofit of unreinforced brick masonry buildings. In Proceedings of the Brick and Block Masonry-From Historical to Sustainable Masonry-Proceedings of the 17th International Brick/Block Masonry Conference (17thIB2MaC 2020), Kraków, Poland, 5-8 July 2020.

47. Margani, G.; Evola, G.; Tardo, C.; Marino, E.M. Energy, seismic, and architectural renovation of RC framed buildings with prefabricated timber panels. Sustainability 2020, 12, 4845. [CrossRef]

48. Straube, J.; Schumacher, C. Interior insulation retrofits of load-bearing masonry walls in cold climates. J. Green Build. 2007, 2, 42-50. [CrossRef]

49. Mensinga, P.; Straube, J.; Schumacher, C. Assessing the freeze-thaw resistance of clay brick for interior insulation retrofit projects. In Proceedings of the Thermal Performance of the Exterior Envelopes of Whole Buildings-11th International Conference, Clearwater, FL, USA, 5-9 December 2010.

50. Wilkinson, J.; DeRose, D.; Straube, J.F.; Sullivan, B. Measuring the Impact of Interior Insulation on Solid Masonry Walls in a Cold Climate. In Proceedings of the Canadian Building Science \& Technology Conference, Montreal, QC, Canada, 6-8 May 2009.

51. Guizzardi, M.; Derome, D.; Vonbank, R.; Carmeliet, J. Hygrothermal behavior of a massive wall with interior insulation during wetting. Build. Environ. 2015. [CrossRef]

52. Moradias, P.A.; Silva, P.D.; Castro-Gomes, J.P.; Salazar, M.V.; Pires, L. Experimental study on hygrothermal behaviour of retrofit solutions applied to old building walls. Constr. Build. Mater. 2012. [CrossRef]

53. Abdul Hamid, A.; Wallentén, P. Hygrothermal assessment of internally added thermal insulation on external brick walls in Swedish multifamily buildings. Build. Environ. 2017. [CrossRef]

54. Yoo, J.; Chang, S.J.; Lee, J.; Wi, S.; Kim, S. Numerical analysis of hygrothermal properties and behavior of Korean based cross-laminated timber (CLT) wall system to deduce optimal assemblies. J. Clean. Prod. 2019, 213, 1217-1227. [CrossRef]

55. McClung, R.; Ge, H.; Straube, J.; Wang, J. Hygrothermal performance of cross-laminated timber wall assemblies with built-in moisture: Field measurements and simulations. Build. Environ. 2014, 71. [CrossRef]

56. Cho, H.M.; Wi, S.; Chang, S.J.; Kim, S. Hygrothermal properties analysis of cross-laminated timber wall with internal and external insulation systems. J. Clean. Prod. 2019, 231. [CrossRef]

57. Chang, S.J.; Wi, S.; Kang, S.G.; Kim, S. Moisture risk assessment of cross-laminated timber walls: Perspectives on climate conditions and water vapor resistance performance of building materials. Build. Environ. 2020. [CrossRef]

58. Di Perna, C.; Stazi, F.; Casalena, A.U.; D'Orazio, M. Influence of the internal inertia of the building envelope on summertime comfort in buildings with high internal heat loads. Energy Build. 2011. [CrossRef] 
59. Adekunle, T.O.; Nikolopoulou, M. Thermal comfort, summertime temperatures and overheating in prefabricated timber housing. Build. Environ. 2016. [CrossRef]

60. Dartwin Mold Simulator. Available online: https://www.dartwin.it/it/ (accessed on 31 March 2020).

61. Strand7 Pty Ltd. Using Strand7-Introduction of the Strand7 Finite Element Analysis System, 3rd ed.; Strand7 Pty Ltd.: Sydney, Australia, 2010; ISBN 0646372882.

62. Ma, R.; Jiang, L.; He, M.; Fang, C.; Liang, F. Experimental investigations on masonry structures using external prestressing techniques for improving seismic performance. Eng. Struct. 2012, 42, 297-307. [CrossRef]

63. EN 14080:2013 - Timber Structures—Glued Laminated Timber and Glued Solid Timber-Requirements; European Committee for Standardization: Brussels, Belgium, 2013.

64. UNI 10351:2015-Building Materials and Construction Products-Thermohygrometric Properties_Procedure for Choosing Design Values; Italian National Unification Body: Milan, Italy, 2015. (In Italian)

65. EN 1008-3:2014—Stainless Steels Part 3: Technical Delivery Conditions for Semi-Finished Products, Bars, Rods, Wire, Sections and Bright Products of Corrosion Resisting Steels for General Purposes; European Committee for Standardization: Brussels, Belgium, 2014.

66. NTC2018 D.M. Aggiornamento Delle "Norme Tecniche per le Costruzioni"; Official Gazette of the Italian Republic: Rome, Italy, 2018. (In Italian)

67. Ministero delle Infrastrutture e dei Trasporti Circolare 21 Gennaio 2019 n.7_Istruzioni per l'applicazione dell' «Aggiornamento delle "Norme Tecniche Per le Costruzioni"» di cui al Decreto Ministeriale 17 Gennaio 2018. (Italian Guideline); Official Gazette of the Italian Republic: Rome, Italy, 2019. (In Italian)

68. EN ISO 6946:2017-Building Components and Building Elements-Thermal Resistance and thermal transmittance-Calculation Methods; European Committee for Standardization: Brussels, Belgium, 2017.

69. EN ISO 13786:2017-Thermal Performance of Building Components_Dynamic Thermal Characteristics_Calculation Methods; European Committee for Standardization: Brussels, Belgium, 2017.

70. D. Lgs. 192/2005 Implementation of Directive 2002/91/EC on Energy Performance in Buildings; Official Gazette of the Italian Republic: Rome, Italy, 2005. (In Italian)

71. DPR 59/2009 Implementation Regulation of Article 4, Paragraph 1, Letters a) and b), of the Legislative Decree n. 192/2005, Concerning the Implementation of Directive 2002/91/EC on Energy Performance in Buildings; Official Gazette of the Italian Republic: Rome, Italy, 2009; pp. 1-28. (In Italian)

72. Sedlbauer, K. Prediction of mould fungus formation on the surface of and inside building components. Fraunhofer Inst. Build. Phys. 2001, 247, 75-141.

73. Silveira, V.D.C.; Pinto, M.M.; Westphal, F.S. Influence of environmental factors favorable to the development and proliferation of mold in residential buildings in tropical climates. Build. Environ. 2019, 166, 106421. [CrossRef]

74. Hwang, K.i.; Jeong, Y.S.; Han, J. Indoor condensation prediction based on a surface temperature estimation. Int. J. Commun. Syst. 2019, 1-13. [CrossRef]

75. Szokolay, S.V. Climate analysis based on the psychrometric chart. Int. J. Ambient Energy 1986, 7. [CrossRef]

76. Smith, K.M.; Svendsen, S. The effect of a rotary heat exchanger in room-based ventilation on indoor humidity in existing apartments in temperate climates. Energy Build. 2016, 116, 349-361. [CrossRef]

77. Horan, P.; Luther, M. Using th psychrometric chart in building measurments. In Proceedings of the 44th Annual Conference of the Architectural Science Association, Auckland, New Zealand, 24-26 November 2010.

78. Shah, D.J.; Krueger, J.H.; Strand, R.L. Indoor Climate Controlled System Adjusting oth Dry-Bulb Temperature and Wet-Bulb or Dew Point Temperature in the Enclosure; U.S. Patent No. 5,346,129; U.S. Patent and Trademark Office: Washington, DC, USA, 1994.

79. Huang, Y.; Zhang, K.; Yang, S.; Jin, Y. A method to measure humidity based on dry-bulb and wet-bulb temperatures. Res. J. Appl. Sci. Eng. Technol. 2013, 6, 2984-2987. [CrossRef]

80. Stucchi, M.; Meletti, C.; Montaldo, V.; Akinci, A.; Faccioli, E.; Gasperini, P.; Malagnini, L.; Valensise, G. Pericolosità Sismica di Riferimento per il Territorio Nazionale MPS04 [Data Set]; Istituto Nazionale di Geofisica e Vulcanologia (INGV): Rome, Italy, 2004. [CrossRef]

81. DM 26/06/2015-Italian Interministerial Decree: Application of Calculation Methods for Energy Performance and Definition of Minimum Building Requirements; Official Gazette of the Italian Republic: Rome, Italy, 2015. (In Italian) 